\title{
Faktor Pengaruh Tingkat Kepuasan Kinerja Pramugari Perusahaan Transportasi Bis Joglosemar (PT. Sejahtera AO Kencana Sakti)
}

\author{
Wahyu Adi Prabowo ${ }^{1 *}$, Fauzan Romadlon ${ }^{2}$ \\ 1*) Program Studi Informatika, Fakultas Informatika, Institut Teknologi Telkom Purwokerto \\ ${ }^{2}$ Program Studi Teknik Industri, Fakultas Rekayasa Industri dan Desain, Institut Teknologi \\ Telkom Purwokerto \\ Jalan D.I. Panjaitan 128, Purwokerto, Indonesia, 53147 \\ E-mail: wahyuadi@ittelkom-pwt.ac.id $\left.{ }^{1 *}\right)$
}

\begin{abstract}
ABSTRAK
Aktivitas perusahaan yang cepat menimbulkan sebuah iklim lingkungan yang ketat dan bahkan keras, sehingga diperlukan sebuah motivasi kerja yang baik. Peranan motivasi kerja sangat mempengaruhi dalam pencapaian tujuan sebuah organisasi. Tujuan dari penelitian ini adalah untuk mengetahui kepuasan kerja berdasarkan faktor aspek gaji, pengembangan diri (karir), kebijakan pimpinan, hubungan rekan kerja, loyalitas, dan prestasi pada divisi pramugari di perusahaan transportasi bis Joglosemar. Data dalam penelitian ini diolah dengan menggunakan skala L1ikert yang digunakan untuk mengukur kepuasan kinerja pramugari bis Joglosemar yang berjumlah 15 orang, lalu dianalisa dengan menggunakan metode kualitatif untuk membandingkan dengan teori kepuasan kerja. Hasil penelitian menunjukkan bahwa tingkat kepuasan kerja pramugari bis Joglosemar cenderung tinggi. Nilai tertinggi adalah aspek hubungan rekan kerja dan nilai yang terendah adalah gaji dan pengembangan diri (karir). Hasil penelitian juga membuktikan bahwa akibat dari rendahnya kepuasan kerja terhadap aspek gaji mengakibatkan adanya sebuah penyimpangan kerja yang dilakukan oleh pramugari bis, yaitu dengan menaikkan penumpang secara ilegal.
\end{abstract}

Kata kunci: Joglosemar; Kepuasan Kerja; Pramugari; Transportasi

\begin{abstract}
The company's rapid activity is strict and even harsh environment, so it needs a right work motivation. The role of work motivation is very influential in achieving the goals of an organization. The purpose of this study is to determine job satisfaction based on salary, career development, leadership policies, colleague relations, loyalty, and achievement. The study is conducted at the bus attendant division at the Joglosemar bus transportation company. The collected data is processed using a Likert Scale, which is used to measure the satisfaction of 15 Joglosemar bus attendant performances. Then, it is analyzed using qualitative methods to compare with job satisfaction theory. The results showed that the job satisfaction level of Joglosemar bus attendants tend to be high. The highest value is the aspect of colleague relations, and the lowest value is salary and career development. The results show that the low job satisfaction from salary effects to a work deviation that is carried out by bus attendant, namely by picking up passengers illegally.
\end{abstract}

Keyword: Joglosemar; Job Satisfaction; Bus Attendant; Transportation 


\section{PENDAHULUAN}

Kepuasan kerja selayaknya tidak hanya dipandang sebagai objek dalam pencapaian tujuan perusahaan, dimana karyawan hanya dipandang dan disertakan dalam faktor produksi. Tetapi karyawan harus dipandang lebih dari itu yaitu diperlakukan sebagai subjek. Hal ini mengingat bahwa kepuasan kerja juga berfungsi sebagai perencana, pelaksana, dan pengendalian yang berperan aktif dalam pencapaian tujuan dari perusahaan. Beberapa ciri perusahaan yang baik adalah menekankan kepada visi kerja, nilai dan ekspektasi, dan memiliki staff yang kompeten sehingga memunculkan aksi nyata dengan memunculkan attitude atau sikap yang baik karyawannya (Olivier-Pijpers, Cramm, and Nieboer, 2020). Terkadang, beberapa sikap yang diperlihatkan oleh karyawan dipengaruhi oleh kebiasaan supervisornya dan adanya proses moral decoupling dari supervisornya (Fehr et al., 2019).

Sikap karyawan terhadap pekerjaannya akan berpengaruh terhadap motivasi dan kecintaan terhadap pekerjaannya. Motivasi dan kecintaan (kepuasan kerja) ini akan berpengaruh pada kinerja karyawan (Bandhaso dan Paranoan Natalia, 2009). Selain itu, kinerja karyawan memiliki korelasi positif dengan adanya keterlibatan aktif karyawan, beban kerja yang diberikan, dan budaya kerja yang dibentuk (Nasution, 2017). Faktanya, budaya kerja yang tinggi akan berdampak pada penghasilan karyawan dan waktu kerja yang lebih singkat (Bhardwaj, Mishra, and Kumar Jain, 2020). Sedangkan ketidakmampuan karyawan dalam mengikuti budaya kerja akan berdampak pada rendahnya kepuasan kerja, dan keefektifan sebuah program kerja yang dijalankan seperti kerja sama yang kurang, fokus pada pelanggan menurun, dan usaha perbaikan yang tidak dilakukan terus menerus (Morrow, Mcelroy, and Scheibe, 2011).

Kepuasan kerja sendiri dipengaruhi beberapa hal yaitu, sikap dan superioritas atasan, hubungan antar karyawan, suasana kerja, promosi dan gaji (Syahruddin, 2016). Sehingga bila beberapa hal tersebut tidak dipenuhi maka akan timbul ketidakpuasan karyawan sehingga menurunkan motivasi dan performansi kerjanya (Muayyad dan Gawi, 2017; Gimon, Fatoni, dan Minarsih, 2018; dan Damayanti, Hanafi, dan Cahyadi, 2018). Kepuasan kinerja yang rendah terkadang dipengaruhi oleh ambiguitas peran dalam sebuah pekerjaan dan adanya konflik terhadap peran tersebut. Efeknya adalah pada pengalaman kerja dan persepsi yag negatif dalam kegiatan profesional (Orgambidez and Almeida, 2020).

Beberapa kondisi kepuasan kerja juga dipengaruhi oleh kondisi lingkungan. Pada pekerjaan yang mempunyai resiko akustik yang tinggi, kepuasan kerja tidak terpengaruh dengan adanya gangguan noise (Park et al., 2020). Akan tetapi, sebuah tempat kerja juga tetap harus menerapkan safety behaviour dengan meningkatkan sistem manajemen keselamatan 
(Liu et al., 2020). Faktanya, ketidakamanan dalam pekerjaan tidak memiliki korelasi positif dengan sikap organisasi melainkan berkorelasi positif dengan kesehatan karyawan dan kesejahteraannya (Yaslioglu, Karagulle, and Baran, 2013). Ditambah lagi, kesempatan dalam berkawan dan prevalensinya sebuah pekerjaan, memiliki resiko negatif terhadap produktivitas kerja (Zhuang et al., 2020).

Selain budaya kerja, dibutuhkan pula sebuah desain pekerjaan. Desain pekerjaan yang sesuai akan meningkatkan motivasi karyawan, manfaat bagi pelanggan, dan meningkatkan pelayanan dengan kualitas yang tinggi (Ho and $\mathrm{Wu}$, 2019). Sebagaimana perusahaan transportasi khususnya pada driver sebuah bus, desain pekerjaan yang menjadikan seorang driver merasa puas adalah pengalaman mengemudi yang lama sehingga meningkatkan pendapatan mereka (Kwon, Byun, and Park, 2020). Ditambah lagi, pada cabin crew pesawat udara, dibutuhkan sebuah budaya perusahaan dan identitas pada performansi pekerjaan dan keramahaan yang ditawarkan untuk kelangsungan bisnis jangka panjang (Okabe, 2017).

Bisnis transportasi memang tidak bias gender, akan tetapi keterlibatan perempuan dalam bisnis ini hendaknya diperhitungkan. Hal ini terjadi pula pada karyawan khususnya pada divisi pramugari di perusahaan transportasi bis Joglosemar (PT. Sejahtera AO Kencana Sakti). perusahaan transportasi bis Joglosemar merupakan satu-satunya agen transportasi yang menyediakan fasilitas pramugari selama perjalanan. Joglosemar lahir dari konsep transportasi post-modernisme yang menekankan layanan personal, dimana penumpang senantiasa diperlakukan sebagai subjek, yang berhak mendapatkan layanan lebih baik bahkan kita juga menyediakan layanan lain di atas kendaraan selama dalam perjalanan, seperti antara lain melakukan reconfirm ticket pesawat, booking ticket pesawat, hotel reservation, car rental, sampai dengan paket tour. Sehingga bagi kalangan sosial tertentu, Joglosemar menjadi sebuah kebutuhan yang memang harus ada di tengah kemajemukan masyarakat kita dewasa ini.

Selain itu, perusahaan juga meyakini bahwa pola operasional Joglosemar memberikan nilai tambah dalam khasanah moda transportasi darat yang ada saat ini. Pola yang unik, berbeda baik secara esensial maupun substansial. Pola yang dijalankan Joglosemar mampu menjawab kebutuhan sebagian warga masyarakat yang mengharapkan satu moda transportasi umum yang lebih personalize dan memiliki nilai jual yang baik bagi dunia pariwisata sebagaimana keberadaan Greyhound di Australia, Amtrax di Eropha dan Greyland di USA. Beberapa hal tersebut adalah dasar pembentukan divisi pramugari di perusahaan transportasi bis Joglosemar.

Divisi pramugari ini merupakan ciri khas Joglosemar. divisi pramugari ini meniru 
konsep pramugari pada transportasi pesawat udara yaitu melayani dan memberikan bantuan bagi para penumpang selama perjalanan. Pada sisi deskripsi pekerjaan dapat dikatakan hampir sama, akan tetapi di sisi kepuasan pekerjaan kemungkinan berbeda. Lebih lanjut lagi, alasan tambahan diadakannya divisi pramugari ini adalah sebagai ikon Joglosemar, membantu apabila ada penumpang yang kesulitan selama perjalanan, pramugari dapat menjelaskan tempat-tempat yang dilalui selama perjalanan dan biasanya pramugari juga diberi tugas khusus untuk mengangkat telepon dari kantor pusat untuk memberitahukan keberadaan armada.

Oleh karena itu, dibutuhkan suatu penelitian untuk mengetahui faktor yang mempengaruhi kepuasan kerja divisi pramugari di perusahaan transportasi bis Joglosemar. Hal ini bertujuan untuk mengukur dampak kepuasan kerja terhadap performansi pramugari. Performansi yang optimal akan berdampak positif pada tingkat pelayanan penumpang.

Latar belakang perempuan bekerja adalah karena kondisi ekonomi meski beberapa kasus terhalang oleh nilai-nilai tradisional (April, 2016). Selain itu, perempuan yang bekerja bertujuan agar perempuan ikut berkontribusi atau berpartisipasi dalam pembangunan sosial ekonomi (Bamwesigye and Hlavackova, 2019). Ditambah lagi, perwujudan kesetaraan gender khusunya dalam bidang transportasi adalah adalah adanya keterlibatan wanita pada proses pengambilan keputusan, keterlibatan langsung, serta monitoring bias gender (Hamilton et al.,, 2005).

Beberapa hal yang berpengaruh terhadap kepuasan kerja adalah pekerjaan yang secara mental menantang, dimana karyawan cenderung menyukai pekerjaan yang memberi kesempatan untuk menggunakan kemampuan, keterampilan dan kebebasan berekspresi. Selanjutnya, adanya ganjaran yang pantas yaitu setiap karyawan, kondisi kerja yang mendukung, rekan kerja yang mendukung yang selalu memberi dukungan untuk dapat maju. Selain itu, perlunya kesesuaian antara kepribadian dan pekerjaan, dimana karyawan dapat melakukan pekerjaan yang optimal yaitu dengan adanya kesesuaian keterampilan dan keahlian yang dimiliki (Wexley and Yukl, 1984).

\section{METODE PENELITIAN}

Penelitian ini didahului dengan survei pendahuluan pada objek penelitian. Survei pendahuluan bertujuan untuk menggambarkan kondisi pramugari perusahaan transportasi bis Joglosemar. Data diambil sejumlah 15 yang meliputi keseluruhan jumlah pramugari perusahaan transportasi bis Joglosemar. Pengumpulan data dilakukan dengan wawancara langsung kepada pramugari dan pengisian kuesioner dilakukan secara langsung. Kriteria 
preferensi yang diukur berdasarkan aspek gaji, karir atau pengembangan diri, kebijaksanaan pimpinan, hubungan rekan kerja, loyalitas dan prestasi. Adapun penjabaran dari setiap aspek dapat dilihat pada Tabel 1 (Wexley and Yukl, 1984). Data diolah secara kuantitatif dan dengan pendekatan kuantitatif ini digunakan untuk mengukur tingkat kepuasan kinerja pramugari. Preferensi ini diukur dengan skala Likert. Selain itu, digunakan metode kualitatif, yaitu dengan membandingkan dengan teori kepuasan kinerja.

Tabel 1. Aspek Kepuasan Kinerja Pramugari

\begin{tabular}{|c|c|c|}
\hline No. & Aspek & Pernyataan \\
\hline 1 & Gaji & $\begin{array}{l}\text { 1. Kehidupan kurang terjamin kalau bekerja di perusahaan ini. } \\
\text { 2. Kebutuhan dapat terpenuhi setelah bekerja di perusahaan ini. } \\
\text { 3. Merasa senang bekerja di perusahaan karena selain gaji dapat insentif dan } \\
\text { THR. } \\
\text { 4. Gaji yang dibayarkan kepada karyawan selama ini kurang bisa memenuhi } \\
\text { kebutuhan meskipun ada standar UMR. }\end{array}$ \\
\hline 2 & $\begin{array}{l}\text { Pengembangan } \\
\text { diri (karir) }\end{array}$ & $\begin{array}{l}\text { 1. Peluang dan kesempatan untuk maju sering didapatkan di perusahaan ini. } \\
\text { 2. Merasa sulit berkembang bila tetap bekerja di perusahaan ini. } \\
\text { 3. Merasa karir saya tidak mengalami peningkatan setelah sekian lama } \\
\text { bekerja di perusahaan ini. } \\
\text { 4. Peluang karir terhambat akibat adanya diskriminasi dalam perusahaan ini. }\end{array}$ \\
\hline 3 & $\begin{array}{l}\text { Kebijaksanaan } \\
\text { Pimpinan }\end{array}$ & $\begin{array}{l}\text { 1. Kebijaksanaan yang dikeluarkan oleh pihak perusahaan sangat membantu } \\
\text { dan mendukung kepentingan seluruh pegawai. } \\
\text { 2. Merasa puas bekerja di perusahaan ini karena cocok dengan pimpinan. } \\
\text { 3. Merasa lingkungan kerja saya sangat menghambat prestasi kerja saya. } \\
\text { 4. Kebijaksanaan yang diterapkan di perusahaan ini kurang begitu } \\
\text { mempertimbangkan dengan kondisi pegawai. }\end{array}$ \\
\hline 4 & $\begin{array}{l}\text { Hubungan } \\
\text { Rekan Kerja }\end{array}$ & $\begin{array}{l}\text { 1. Hubungan dengan rekan sekerja diwarnai dengan persaingan. } \\
\text { 2. Lingkungan kerja di perusahaan ini membuat termotivasi untuk } \\
\text { berprestasi. } \\
\text { 3. Merasa tertekan dengan lingkungan kerja saya yang kurang nyaman. } \\
\text { 4. Mendapat dukungan dari teman-teman sekerja untuk memacu semangat } \\
\text { kerja saya. }\end{array}$ \\
\hline 5 & Loyalitas & $\begin{array}{l}\text { 1. Kurang menyukai gaya kepemimpinan atasan sehingga saya ingin pindah } \\
\text { ke bagian lain atau pimpinan diganti yang lebih baik. } \\
\text { 2. Masih berkeinginan mencari perusahaan lain yang lebih baik untuk } \\
\text { pindah kerja. } \\
\text { 3. Cara kepemimpinan atasan di perusahaan ini membuat saya senang dan } \\
\text { puas menjadi bawahan. } \\
\text { 4. Merasakan ada diantara teman-teman yang ingin pindah kerja namun saya } \\
\text { masih merasa nyaman bekerja di perusahaan ini }\end{array}$ \\
\hline 6 & Prestasi & $\begin{array}{l}\text { 1. Merasa banyak mendapat pengalaman selama bekerja di perusahaan ini. } \\
\text { 2. Atasan kurang begitu menghargai prestasi kerja selama ini } \\
\text { 3. Merasa apa yang diharapkan di perusahaan ini sesuai dengan jerih payah } \\
\text { (kerja). } \\
\text { 4. Tidak pernah diberi kesempatan untuk dipromosikan. }\end{array}$ \\
\hline
\end{tabular}

Sumber: Data Analisa Aspek Kepuasan, 2020

Analisa data yang digunakan untuk mengetahui faktor-faktor yang berpengaruh pada tingkat kepuasan kinerja pramugari perusahaan transportasi bis Joglosemar, peneliti 
menggunakan pengukuran yang berbentuk kuisioner skala Likert. Skala ini merupakan skala yang diguanakan secara sistematis untuk menunjukkan sikap. Dengan menggunakan skala Likert ini, indikator variabel dijadikan titik tolak acuan dalam menyusun instrument pernyataan maupun pertanyaan. Peneliti menggunakan skala Likert dengan empat pilihan jawaban yang dapat dilihat pada tabel berikut.

Tabel 2. Skala Likert

\begin{tabular}{cc}
\hline Alternatif Jawaban & Nilai Item \\
\hline Sangat Tidak Setuju & 1 \\
Tidak Setuju & 2 \\
Setuju & 3 \\
Sangat Setuju & 4 \\
\hline
\end{tabular}

Sumber: Hadi, 1991

Dalam penelitian ini juga menggunakan metode analisis deskriptif untuk menjelaskan tentang variable-variabel yang digunakan karena bersifat kualitatif. Dalam menjawab hasil masing-masing variabel penelitian digunakan juga penilaian rata-rata. Rumus yang digunakan adalah:

$$
\text { Panjang kelas interval }=\frac{\text { Rentang }}{\text { Banyak Kelas Interval }}
$$

Keterangan:

Rentang

Banyak kelas Interval

Panjang Kelas Interval
$=$ Nilai tertinggi-Nilai Terendah

= Banyaknya kelas yang diinginkan

$=$ Interval kelas

Rumus ini adalah untuk mencari persentase penilaian pencapaian skor, yang sehingga di dapatkan nilai masing-masing kelas untuk skor kepuasan kerja dalam tabel berikut:

\section{Tabel 2. Skala Likert}

\begin{tabular}{cc}
\hline Persentase Pencapaian Skor & Penilaian \\
\hline $78-96$ & Sangat Puas \\
$60-77$ & Puas \\
$42-59$ & Tidak Puas \\
$24-41$ & Sangat Tidak Puas \\
\hline
\end{tabular}

Sumber: Data Persentase Pencapaian Skor

\section{HASIL DAN PEMBAHASAN}

Perhitungan yang digunakan adalah berupa skala Likert. Skala kepuasan kerja berjumlah 24 butir pernyataan dengan 4 pilihan jawaban, yaitu Sangat Tidak Setuju (STS), Tidak Setuju (TS), Setuju (S), Sangat Setuju (SS). Pemberian skor untuk jawaban subjek dalam item yang favorable adalah 1 untuk respon STS, 2 untuk respon TS, 3 untuk respon S, 
dan 4 untuk respon SS. Sedangkan pemberian skor untuk jawaban subjek dalam item yang unfavorable adalah 4 untuk respon STS, 3 untuk respon TS, 2 untuk respon S, dan 1 untuk respon SS. Semakin tinggi skor yang diperoleh subjek, maka semakin tinggi pula tingkat kepuasan kerjanya, begitu juga sebaliknya. Tabel skor setiap subjek dapat dilihat pada berikut.

Tabel 3. Skor Kepuasan Kerja Per-Pramugari

\begin{tabular}{cc}
\hline No. Subjek & Skor \\
\hline 1 & 55 \\
2 & 42 \\
3 & 48 \\
4 & 51 \\
5 & 57 \\
6 & 59 \\
7 & 52 \\
8 & 54 \\
9 & 49 \\
10 & 56 \\
11 & 50 \\
12 & 56 \\
13 & 49 \\
14 & 51 \\
15 & 56 \\
Total & 785 \\
Rata-Rata & 52,33 \\
Sumber: Hasil Analisa Tingkat Skor Kepuasan Kerja, 2020
\end{tabular}

Berdasarkan Tabel 3 dapat dilihat bahwa rata-rata skor subjek adalah 52,33. Range skor untuk skala ini adalah 24 -96, dengan median 51. Hal tersebut menunjukkan bahwa skor ratarata subjek berada di atas nilai median. Sementara itu skor tertinggi subjek adalah 59, berada di atas nilai median, dan skor terendah adalah 42 yang berada di bawah nilai median. Berdasarkan data tersebut menunjukkan bahwa tingkat kepuasan kerja pramugari Joglosemar secara umum cenderung tinggi.

Tabel 4. Total Skor Per Aspek

\begin{tabular}{clcc}
\hline No & \multicolumn{1}{c}{ Variabel } & Total & Rata-Rata \\
\hline 1 & Gaji & 96 & 6,4 \\
2 & Pengembangan diri (karir) & 109 & 7,3 \\
3 & Kebijaksanaan Pemimpin & 141 & 9,4 \\
4 & Hubungan Rekan Kerja & 159 & 10,6 \\
5 & Loyalitas & 145 & 9,7 \\
6 & Prestasi & 135 & 9 \\
\hline
\end{tabular}

Sumber: Hasil Analisa Total Skor Per Aspek, 2020

Selanjutnya, pada Tabel 4 menunjukkan bahwa aspek kepuasan kerja dengan skor tertinggi adalah hubungan rekan kerja. Sementara untuk skor terendah adalah gaji, disusul 
oleh pengembangan diri (karir). Kepuasan yang rendah dari aspek gaji dimungkinkan terjadi karena memang gaji sangat rendah, yaitu Rp 40.000/PP, artinya, dalam sekali jalan pulang pergi selama 6 jam, hanya diberi fee sebesar Rp 40.000. Rata-rata gaji pramugari setiap bulannya berkisar antara Rp 1.000 .000 s/d Rp 1.500.000. Skor rendah juga dimiliki oleh aspek pengembangan diri (karir), hal ini terjadi karena memang tidak adanya jenjang karir untuk divisi pramugari. Pramugari tidak bisa naik jabatan menjadi front officer atau bagian yang lain, karena pramugari merupakan karyawan kontrak. Skor tertinggi untuk aspek kepuasan kerja adalah hubungan rekan kerja. Hal ini menandakan bahwa terjadi hubungan yang cukup baik dan harmonis antar pramugari atau antar karyawan lintas divisi.

Kepuasan kerja tergantung dari perbedaan antara apa yang seharusnya ada (kebutuhan, harapan, dan nilai) dengan apa yang menurut perasaan atau persepsi telah diperoleh melalui pekerjaan (Wexley and Yukl, 1984). Terdapat pandangan dari Porter yang disebut dengan Discrepancy Theory. Apabila hasilnya lebih besar dari yang seharusnya ada, maka akan menciptakan rasa puas walaupun ada discrepancy, hal ini disebut discrepancy positive. Akan tetapi, jika kenyataan yang didapat jauh dari minimum maka akan terjadi ketidakpuasan, hal ini disebut discrepancy negative.

Di sisi lain, berdasarkan hasil studi ditemukan satu hal yang menarik dari wawancara dengan manajer HRD dan koordinator pramugari yang berkaitan dengan hasil kuesioner yang menunjukkan bahwa faktor gaji mempunyai skor terendah. Faktor gaji yang rendah ternyata menimbulkan penyimpangan yang beberapa kali terjadi, yaitu pramugari bekerjasama dengan driver dan co-driver menaikkan penumpang secara ilegal di tengah jalan, tanpa memberitahukan kepada agen atau shelter atau kantor pusat pemesanan tiket. Uang tiket dari penumpang dibagi rata pramugari, driver, dan co-driver. Bentuk sanksi yang diberikan jika pramugari melakukan kecurangan seperti itu akan langsung dipecat tanpa peringatan terlebih dahulu.

Menurut Wexley and Yukl (1984), kepuasan maupun ketidakpuasan tergantung apakah dia merasakan keadilan (equity) atau tidak terhadap sesuatu dengan cara membandingkan dirinya dengan orang lain. Dalam teori ini terdapat tiga elemen yaitu input, outcomes, dan orang pembanding dan adanya situasi equity-inequity. Input segala sesuatu yang berharga yang dirasakan karyawan sebagai hasil dari sumbangan pekerjaanya, misalnya pendidikan, pengalaman, keterampilan, jam kerja dan sebagainya). Outcomes merupakan sesuatu yang berharga yang diterima karyawan sebagi hasil dari pekerjaannya, misalnya gaji, kesempatan berprestasi, simbol status, dan pengakuan. Dalam teori tersebut, seseorang menilai fair hasilnya dengan membandingkan faktor input dan outcomes yang dimiliki dengan orang lain. 
Sedangkan yang menjadi orang pembanding yaitu orang yang bekerja di perusahaan yang sama atau lain atau dirinya dengan masa lampau. Apabila perbandingan dirasakan adil (equity) maka akan puas begitu pula sebaliknya (Wexley and Yukl, 1984).

Lebih lanjut, Baron and Greenberg (1990), kepuasan maupun ketidakpuasan kerja merupakan dua hal yang berbeda yaitu kepuasan dan ketidakpuasan kerja merupakan suatu variabel yang bisa digambarkan dalam satu kontinum kepuasan dan ketidakpuasan. Pendapat tersebut disebut Two Factor Theory, dengan membagi situasi yang mempengaruhi sikap seseorang terhadap pekerjaannya menjadi dua kelompok yaitu kelompok satisfiers kadangkadang diberi nama intrinstik factor, job content, dan motivator, dan kelompok dissatisfiers biasa disebut dengan ekstrinsik factor, job context, dan hygiene factor (Baron and Greenberg, 1990).

Satisfiers merupakan faktor yang dibuktikan sebagai sumber kepuasan, misalnya tanggung jawab, prestasi kerja, pengetahuan dan pengenalan terhadap pekerjanya, pekerjaan itu sendiri, dan pengembangan diri. Faktor-faktor ini akan menimbulkan kepuasan tapi tidak hadirnya faktor-faktor ini tidak selalu mengakibatkan ketidakpuasan. Sedangkan dissatisfiers merupakan faktor-faktor yang terbukti menjadi faktor sumber ketidakpuasan, misalnya peraturan dan administrasi perusahaan, teknik pengawasan, upah, hubungan interpersonal, kondisi kerja, keamanan, status. Perbaikan terhadap kondisi ini akan mengurangi ketidakpuasan tetapi tidak akan menimbulkan kepuasan karena bukan merupakan sumber kepuasan. Lebih lanjut lagi kelompok yang dapat memacu seseorang untuk bekerja dengan baik dan bergairah hanyalah kelompok satisfiers (Baron and Greenberg, 1990).

Selanjutnya dinyatakan bahwa dimensi manakah suatu pekerjaan itu memuaskan atau tidak. Sangat tergantung pada iklim sikap kerja masing-masing pribadi. Bagaimana seseorang menyikapi kerja secara positif atau negatif, artinya apabila setiap orang mampu menyikapi tugas pekerjaannya secara positif maka kepuasan kerja dapat dicapai, tapi manakala setiap karyawan umumnya kurang mampu menyikapi tugas pekerjaan secara positif atau menyikapi secara negatif, maka kepuasan kerja tidak diperoleh. Jadi kepuasan kerja adalah perwujudan kesukaan atau afeksi seseorang terhadap pekerjaannya (Locke, 1969).

Kepuasan kerja merupakan sikap emosional yang menyenangkan dan mencintai pekerjaannya. Sikap ini dicerminkan oleh moral kerja, kedisiplinan, dan prestasi kerja. Kepuasan kerja dapat dinikmati dalam pekerjaan, luar pekerjaan, dan kombinasi dalam dan luar pekerjaan. Kepuasan dalam pekerjaan adalah kepusasan kerja yang dinikmati dalam pekerjaan dengan memperoleh pujian hasil kerja, penempatan, perlakuan, peralatan, dan suasana lingkungan kerja yang baik. Karyawan yang lebih suka menikmati kepuasan kerja 
dalam pekerjaan akan lebih mengutamakan pekerjaannya daripada balas jasa walaupun balas jasa itu penting. Kepuasan kerja di luar pekerjaan adalah kepuasan kerja karyawan yang dinikmati di luar pekerjaan dengan besarnya balas jasa yang akan diterima dari hasil kerjanya agar dia dapat membeli kebutuhan-kebutuhannya. Karyawan yang lebih suka menikmati kepuasannya di luar pekerjaan lebih mempersoalkan balas jasa daripada pelaksanaan tugastugasnya.

Beberapa rekomendasi yang ditawarkan dalam membantu pemecahan masalah di perusahaan transportasi bis Joglosemar yaitu, dengan menaikkan tingkat kesejahteraan pramugari yaitu dengan menaikkan gaji atau memberikan insentif, karena aspek pembentuk ketidakpuasan kerja tertinggi adalah gaji yang kurang. Perlu diketahui pramugari adalah ikon dari Joglosemar, maka dari itu kami merekomendasikan kepada pihak perusahaan untuk menjadikan pramugari sebagai karyawan tetap, serta memberikan jenjang karir, sehingga karyawan lebih termotivasi dan memiliki sense of belongingness yang tinggi terhadap perusahaan. Selain itu perlunya memberikan reward kepada pramugari dengan performance terbaik, setiap bulan, atau setiap jangka waktu tertentu. Dengan demikian pramugari akan merasa lebih dihargai atas kinerjanya.

\section{KESIMPULAN DAN SARAN}

Penelitian ini dilakukan untuk mengetahui kepuasan kerja pramugari pada perusahaan transportasi bis Joglosemar. Aspek yang dijadikan penilaian meliputi gaji, pengembangan karir, kebijaksanaan pimpinan, hubungan dengan rekan kerja, loyalitas dan prestasi. Setiap pertanyaan yang diajukan memiliki respon yang beragam berdasarkan kondisi pramugari. Secara umum, tingkat kepuasan kerja pramugari Joglosemar cenderung tinggi, Aspek kepuasan kerja pramugari bis Joglosemar dengan skor tertinggi adalah hubungan rekan kerja. Sementara untuk skor terendah adalah gaji, disusul oleh pengembangan diri (karir). Skor rendah untuk gaji ini mengindikasikan adanya ketidakpuasan pramugari. Akhirnya, dampak yang timbul dari ketidakpuasan kerja adalah timbulnya penyimpangan kerja yang dilakukan pramugari, yaitu dengan menaikkan penumpang secara ilegal. Oleh karena itu, dibutuhkan sebuah upaya agar kepuasan kerja ini meningkat sehingga pelayanan pelanggan dapat maksimal.

\section{REFERENSI}

April, A. (2016). Gender and Age Differences in The Travel Behavior - a Novi Sad Case Study. 14, 4324-4333.

Bamwesigye, D., and Hlavackova, P. (2019). Analysis of Sustainable Transport for Smart Cities. 
Bandhaso, M. L., dan Paranoan Natalia. (2009). Pengaruh Kepuasaan Kerja dan Motivasi Kerja terhadap Kinerja Dosen Fakultas Ekonomi di Perguruan Tinggi Swasta di Makasar. Journal of Chemical Information and Modeling, 53(9), 1689-1699.

Baron, R. A., and Greenberg, J. (1990). Behavior in Organizations: Understanding and Managing the Human Side of Work.

Bhardwaj, A., Mishra, S., and Kumar Jain, T. (2020). An analysis to Understanding The Job Satisfaction of Employees in Banking Industry. Materials Today: Proceedings, (xxxx).

Damayanti, R., Hanafi, A., dan Cahyadi, A. (2018). Pengaruh Kepuasan Kerja terhadap Kinerja Karyawan (Studi Kasus Karyawan Non-Medis RS Islam Siti Khadijah Palembang). Jurnal Ilmiah Manajemen Bisnis Dan Terapan, 15(2), 75-86.

Fehr, R., Welsh, D., Yam, K. C., Baer, M., Wei, W., and Vaulont, M. (2019). The Role of Moral Decoupling in The Causes and Consequences of Unethical Pro-Organizational Behavior. Organizational Behavior and Human Decision Processes, 153, 27-40.

Gimon, G. Y. M., Fatoni, A., \& Minarsih, M. M. (2018). Analisis Faktor-Faktor yang Menentukan Kepuasan Kerja Karyawan Rumah Makan Soto Seger Hj.Fatimah Boyolali. Journal Of Management, 4(4).

Hamilton, K., Jenkins, L., Hodgson, F., and Turner, J. (2005). Promoting Gender Equality in Transport.

Ho, C. W., and Wu, C. C. (2019). Using Job Design to Motivate Employees to Improve HighQuality Service in The Airline Industry. Journal of Air Transport Management, 77, 1723.

Kwon, Y., Byun, J., and Park, S. (2020). Exploring The Determinants of Bus Drivers Job Satisfaction: Evidence from South Korea. Research in Transportation Business and Management.

Liu, S. X., Zhou, Y., Cheng, Y., and Zhu, Y. Q. (2020). Multiple Mediating Effects in The Relationship Between Employees' Trust in Organizational Safety and Safety Participation Behavior. Safety Science, 125.

Locke, E. A. (1969). What is Job Satisfaction? Organizational Behavior and Human Performance, 4(4), 309-336.

Morrow, P. C., Mcelroy, J. C., and Scheibe, K. P. (2011). Work Unit Incivility, Job Satisfaction, and Total Quality Management Among Transportation Employees. Transportation Research Part E: Logistics and Transportation Review, 47(6), 1210 1220.

Muayyad, D. M., dan Gawi, A. I. O. (2017). Pengaruh Kepuasan Kerja terhadap Produktivitas Kerja Pegawai Bank Syariah X Kantor Wilayah II. Jurnal Manajemen dan Pemasaran Jasa, 9(1), 75.

Nasution, Y. (2017). Kepuasan Kerja Karyawan pada CV. Mitra Boga Tama. JPPP - Jurnal Penelitian Dan Pengukuran Psikologi, 1(1), 107.

Okabe, N. (2017). Creating of Customer Loyalty by Cabin Crew A Study of The Relation Between Emotional Labor and Job Performance. Transportation Research Procedia, $25,149-164$.

Olivier-Pijpers, V. C., Cramm, J. M., and Nieboer, A. P. (2020). Residents' and Resident Representatives' Perspectives on The Influence of The Organisational Environment on Challenging Behaviour. Research in Developmental Disabilities, 100.

Orgambídez, A., and Almeida, H. (2020). Exploring The Link Between Structural Empowerment and Job Satisfaction Through The Mediating Effect of Role Stress: A Cross-Sectional Questionnaire Study. International Journal of Nursing Studies, 109, 103672 .

Park, S. H., Lee, P. J., Lee, B. K., Roskams, M., and Haynes, B. P. (2020). Associations Between Job Satisfaction, Job Characteristics, and Acoustic Environment in Open-Plan 
Offices. Applied Acoustics, 168, 107425.

Syahruddin. (2016). Faktor-Faktor yang Mempengaruhi Kepuasan Kerja dan Kinerja Karyawan Bank Muamalat Cabang Samarinda. Jurnal Ekonomi dan Manajemen, 13(1), $59-72$.

Wexley, K. N., and Yukl, G. A. (1984). Organizational Behavior and Personnel Psychology. Yaslioglu, M., Karagulle, A. O., and Baran, M. (2013). An Empirical Research on the Relationship between Job Insecurity, Job Related Stress and Job Satisfaction in Logistics Industry. Procedia - Social and Behavioral Sciences, 99, 332-338.

Zhuang, W. L., Chen, K. Y., Chang, C. L., Guan, X., and Huan, T. C. (2020). Effect of Hotel Employees' Workplace Friendship on Workplace Deviance Behaviour: Moderating Role of Organisational Identification. International Journal of Hospitality Management, 88 . 